\title{
Knowledge and use of medicinal plants for users of two basic health units
}

\author{
Conhecimento e uso de plantas medicinais por usuários de duas unidades básicas de saúde \\ Conocimiento y uso de plantas medicinales para usuarios de dos unidades básicas de salud
}

Diego Florêncio Lima ${ }^{1}$, Débora Linsbinski Pereira ${ }^{1}$, Fábio Francoly Franciscon ${ }^{1}$, Claudia dos Reis ${ }^{1}$, Valfran da Silva Lima ${ }^{1}$, Pacífica Pinheiro Cavalcanti ${ }^{1}$

\begin{abstract}
We aimed at verifying the knowledge and use of medicinal plants among users of two Family Health Units. This was a quantitative survey carried out between June and August 2010 at Sinop, Mato Grosso, Brazil. We used a structured interview guide, attended by 302 people of both sexes, which indicated that 77 plants are used for the treatment of several diseases, only $7.67 \%$ did not use medicinal plants. However, we described the 10 most reported plants, the part used for each form and its preparation. Only $0.9 \%$ of the population interviewed acquired information about such plants with health professionals. It is necessary to invest in initiatives that promote greater integration of the use of medicinal plants within the programs developed at Family Health Units, as well as a greater training of these professionals, by incorporating content that include herbal medicine in undergraduate courses.
\end{abstract}

Descriptors: Plants, Medicinal; Phytotherapy; Complementary Therapies.

Objetivou-se verificar o conhecimento e o uso de plantas medicinais entre os usuários de duas Unidades de Saúde da Família. Trata-se de uma pesquisa quantitativa desenvolvida entre junho e agosto de 2010, no município de Sinop, Mato Grosso, Brasil. Foi utilizado um roteiro de entrevista estruturado, no qual participaram 302 pessoas de ambos os sexos, que apontaram 77 plantas utilizadas para o tratamento das mais diversas afecções; somente 7,67\% não utilizavam plantas medicinais. Entretanto, foram descritas as 10 plantas mais citadas, a parte usada de cada uma e sua forma de preparo. Somente $0,9 \%$ da população entrevistada adquiriram informações sobre tais plantas com os profissionais da saúde. Faz-se necessário investir em ações que promovam uma maior integração do uso de plantas medicinais dentro dos programas desenvolvidos nas Unidades de Saúde da Família, bem como uma maior capacitação desses profissionais, por meio da incorporação de conteúdos que contemplem a fitoterapia nos cursos de graduação.

Descritores: Plantas Medicinais; Fitoterapia; Terapias Complementares.

El objetivo fue verificar el conocimiento y el uso de plantas medicinales entre los usuarios en dos Unidades de Salud Familiar. Este fue un estudio cuantitativo llevado a cabo entre junio y agosto de 2010 a Sinop, Mato Grosso, Brasil. Se utilizó una guía de entrevista estructurada, a la que asistieron 302 personas de ambos sexos y éstas mostraron 77 plantas que se utilizan para el tratamiento de varias enfermedades, sólo 7.67\% no utilizaban plantas medicinales. Sin embargo, describimos las 10 plantas de la mayoría de los citados, la parte utilizada para cada forma y su preparación. Sólo 0,9\% de la población entrevistó a la información adquirida acerca de tales plantas con profesionales de la salud. Es necesario invertir en iniciativas que promuevan una mayor integración de la utilización de las plantas medicinales en los programas desarrollados en las Unidades de Salud de la Familia, así como una mayor formación de estos profesionales, mediante la incorporación de contenidos que incluyen las hierbas medicinales en los cursos de pregrado.

Descriptores: Plantas Medicinales; Fitoterapia; Terapias Complementarias.

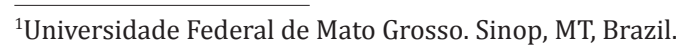




\section{Introduction}

The medicinal plants are defined as the ones which are able to produce active principles which can alter the functioning of the organs and systems, restoring the organic balance or the hemostasis in the cases of diseases ${ }^{(1)}$. Like other therapies they are part of the so-called Traditional Medicine, which is concerning knowledge, abilities and practices based in the theory, beliefs, Indian experiences and of other cultures, used in the maintenance of health in the prevention, improvement or treatment of physical and mental diseases, and it can also be called Complementary Alternative Medicine $\mathrm{P}^{(2)}$.

The first Law related to the use of plants in Brazil is from April, $17^{\text {th }} 1996$, in which the guidelines on medicinal plants were elaborated both regarding their use as well as the research in the area. From this law on, several other Laws and Ordinances were created but the main one is Ordinance no. 971, from May $3^{\text {rd }}, 2006$, which approves the National Policy of Integrative and Complementary Practices in the Unified Health System. This Ordinance allows the users of these services to have access to information regarding the herbal and the medicinal plants directly at the Family Health $\mathrm{Unit}^{(3)}$.

These alternative possibilities of treatment lead to an improvement in the assistance of the population by the Unified Health System, once it provides another form of treatment and prevention of diseases ${ }^{(4)}$.

The use of medicinal plants by the population has contributed not only for the complimentary therapy but also for the directing of phytochemicals studies and the biological activity, such as toxicity, antiinflammatory property and anti-oxidant activity. So the medicinal plants can have the therapeutic actions known for having been later scientifically proved ${ }^{(5)}$.

So the inclusion of therapeutics with medical plants in the community would not only bring benefits to the health of the people, but also benefits related to economy, once the population, in some cases, would not need to buy allopathic medicine ${ }^{(6)}$.

The search for the use of plants from the already existing empiric knowledge, many times consecrated by its continuous use, has guided many researches, however, a great part of the population uses medicinal plants without the knowledge of their toxicity, way of preparation or clinical prescription ${ }^{(6)}$.

The nurse who works in the Family Health Strategy could act in an effective manner in the orientation of the adequate use of this complementary therapeutics, keeping in mind the wide use of medicinal plants by the population who is assisted at a Family Health Unit. So, in order to have proper acting the nurse must first investigate the use of medicinal plants by the community, keeping in mind the obtaining of information on how this population uses the plant, and so elaborate a strategy of education in health and a better quality assistance.

The objective of this research was to verify the knowledge and the use of medicinal plants among the users of the domain of the Family Health Unit.

\section{Method}

It is a research with qualitative approach developed in the county of Sinop, in the north of the State of Mato Grosso, Brazil, located on highway BR163. Sinop has around 114 thousand inhabitants ${ }^{(7)}$, immigrants of several regions of the country where an enormous cultural diversity can be observed.

The city has primary attention through the action of the Family Health Strategy and has 17 Family Health Units. Two units are outstanding for having a greater demand in the assistance, they are the Family Health Units of Boa Esperança and Jardim das Nações which together assist approximately 3000 registered families. So the two units were intentionally chosen for the development of the present investigation.

The data collection was made through a script 
of semi structured interviewed, from June to October, 2010. 302 users of the services participated (100 at the Family Health Unit of Jardim das Nações and 202 at the Family health Unit of Boa Esperança), from June to October, 2010, chosen at random.

As a criterion of inclusion for the participation in the study the following subjects were chosen: Subjects with 18 years of age or more, having no distinction of gender and living in those neighborhoods defined in the study and who were waiting for assistance at the Health Units.

The instrument of data collection was divided into two parts. The first on had variables related to identification of the user and the reason for his going to the Family Health Units. In the second part the user was questioned by the interviewer whether he used medicinal plants as medicine and, if affirmative, which plants they were. The data were statistically analyzed.

The ethical aspects of the research with human beings were respected. The study was approved by the Committee of Ethics and Research of Hospital Universitário Júlio Muller (Cuiabá-MT, Brazil), under no.802/CEP-HUJM/10. The participants made a formal consent in the Free Informed Consent in which the objectives of the research and the required information were explained and the confidentiality of the information and the anonymity of the participants were guaranteed.

\section{Results}

Through the collected data, it was observed that most of the interviewees were from 34 to 41 years of age $(25 \%)$ and $76.8 \%$ were female, showing that the women look for health services more frequently (Table 1).

Concerning the per capita of both samples, $90.07 \%$ of the interviewees belonged to the D and E Economical Social Classes, with a gross monthly family income inferior to $\mathrm{R} \$ 776.00$ (approximately US\$ 343,36 ).
Concerning Schooling a great part of the interviewees (46.7\%) studied incomplete elementary school and only $2 \%$ had finished university (Table 1 ).

Table 1 - Social demographic variables of the sample population

\begin{tabular}{|c|c|c|c|}
\hline \multirow[b]{2}{*}{ Variables } & \multicolumn{2}{|c|}{ Family Health Unit } & \multirow[b]{2}{*}{$\begin{array}{c}\text { Total } \\
\text { No. (\%) }\end{array}$} \\
\hline & $\begin{array}{c}\text { Boa } \\
\text { Esperança } \\
(\text { No.=202) }\end{array}$ & $\begin{array}{c}\text { Jardim das } \\
\text { Nações } \\
(\text { No. }=100)\end{array}$ & \\
\hline \multicolumn{4}{|l|}{ Age (years) } \\
\hline $18-25$ & 19 & 17 & 18 \\
\hline $26-33$ & 25 & 17 & 22 \\
\hline $34-41$ & 27 & 21 & 25 \\
\hline $42-49$ & 15 & 27 & 19 \\
\hline $50-57$ & 8 & 6 & 8 \\
\hline$\geq 58$ & 6 & 12 & 8 \\
\hline \multicolumn{4}{|l|}{ Gender } \\
\hline Female & 74 & 82 & 76.8 \\
\hline Male & 26 & 18 & 23.2 \\
\hline \multicolumn{4}{|l|}{ Schooling } \\
\hline Illiterate & 3 & 3 & 3 \\
\hline Elementary school & 62 & 53 & 61.5 \\
\hline Grade school & 29 & 33 & 29.5 \\
\hline University & 6 & 11 & 6 \\
\hline \multicolumn{4}{|l|}{ Per capita income } \\
\hline$\leq \mathrm{R} \$ 776.00$ & 90.6 & 89 & 90.4 \\
\hline$>\mathrm{R} \$ 776.00$ & 9.4 & 11 & 9.6 \\
\hline
\end{tabular}

The main reasons to go to the health services were resulting of the family assistance in appointments or exams (65\%), blood collection and other secretions (25\%) and other procedures (10\%).

Regarding the use of medicinal plants, $92.3 \%$ reported that they use them as alternative therapy, and they mentioned 77 plants of habitual use for the treatment of the most diversified disorders. The ten most reported plants were described, which part of the plant was used and their manner of preparation (Tables 2 and 3). 
Table 2 - List of the most reported medicinal plants, the main uses and the responsible subjects for the preparation

\begin{tabular}{lllcc}
\hline & \multicolumn{2}{c}{ Plant } & & \multicolumn{2}{c}{$\begin{array}{c}\text { Responsible for the preparation } \\
\text { Interviewee (\%) }\end{array}$} \\
Popular name & Scientific name & Main use & 86.7 & 13.3 \\
\hline Large mint & Mentha piperita L. & Flu, tranquilizers and vermifuge & 92.9 & 7.1 \\
Lemongrass & Cymbopogon citratus Staf & Tranquilizers, flu and antihypertensive & 94.0 & 6.0 \\
Boldo & Plectrathus barbatus Andrews & Stomachache and hangover & 91.7 & 8.3 \\
Pennyroyal & Mentha pulegiumL & Flu, cramps and tranquilizers & 85.0 & 15.0 \\
Mentruz & Lepidium Sativum L. & Wounds, dislocation and vermifuge & 78.6 & 21.4 \\
Bush lemongrass & Libia Alba (Mill) N. E. Brown & Tranquilizers and flu & 85.7 & 14.3 \\
Terramycin & Alternanthera brasiliana (L.) O. Kunt & Infections, wounds and stomachache & 92.3 & 7.7 \\
Cotton & Gossypium hirsutum L. & Infections and urinary infections & 91.7 & 8.3 \\
Aloe vera & Aloe vera (L.) Burm. & Wounds, burns and diabetes & 100.0 & - \\
Chamomile & Chamomilla recutita (L.) Rauschert & Tranquilizers, cramp and stomachache & & \\
\hline
\end{tabular}

Table 3 - Main plants used for therapeutic purposes, according to the way of preparation and parts used

\begin{tabular}{|c|c|c|c|c|c|c|}
\hline \multirow[b]{2}{*}{ Plant (Popular name) } & \multirow[b]{2}{*}{ Mentions (\%)* } & \multirow[t]{2}{*}{ Part of the plant used } & \multicolumn{4}{|c|}{ Way of preparation } \\
\hline & & & Infusion (\%) & Decoction (\%) & Compress (\%) & Juice (\%) \\
\hline Large Mint & 16 & Areal part & 53 & 36 & - & - \\
\hline Lemon Grass & 12 & Complete & 41 & 59 & - & - \\
\hline Boldo & 11 & Leaves & 2,0 & - & - & 92 \\
\hline Pennyroyal & 5 & Areal part & 54 & 42 & - & - \\
\hline Mentruz & 4 & Complete & - & - & 47 & 26 \\
\hline Bush Lemon Grass & 3 & Complete & 36 & 57 & - & - \\
\hline Terramycin & 3 & Complete & 43 & 27 & - & - \\
\hline Cotton & 3 & Leaves and roots & 46 & 23 & & 23 \\
\hline Aloe vera & 3 & Leaves & - & - & 41 & 42 \\
\hline Chamomile & 2 & Flowers & 64 & 36 & - & - \\
\hline
\end{tabular}

* A subject may have reported one or more medicinal plant

When questioned about the place of acquisition of each plant mentioned for usage, most of the subjects (56\%) answered that they cultivated the plants at home; concerning the indication of the plant, $68.7 \%$ stated that the use was indicated by family members.

Regarding the indication of the use of the plants for therapeutic purposes the main source of information were the family members (68.7\%), followed by friends and neighbors (24.3\%), health professionals $(0.9 \%)$ and other kinds of information (6.1\%).
For the use, most of them (56\%) had the plant at home or had other sources of supply, such as neighbors $(15.9 \%)$, relatives $(10.3 \%)$, buying in markets (8.8\%) and other kinds of obtaining (9.3\%).

\section{Discussion}

Studies indicate that people above 35 years of age have the knowledge on the use of medicinal plants, showing that the information on this matter is kept by older people, which probably demonstrates 
that younger people do not care so much for this type of knowledge $\mathrm{e}^{(6,8)}$.

Another datum which should be highlighted is knowledge on the medicinal plants is mainly kept by women; a fact confirmed by other researches and which can be related to the role of the women in the past once they took care of the house, the orchard, the husband and children, besides the elderly and the sick $^{(5,8-12)}$. This differences on the traditional knowledge and the use of medicinal plants among groups of men and women is expected probably by the above mentioned reasons and by the fact that the women are assisting some family member, once the 'female role'

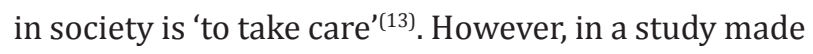
in Itaqui, RS, Brazil, there was no significant difference between male and female users ${ }^{(14)}$.

Concerning the per capita income, despite the fact that many studies do not take into consideration the income of the interviewees, it can be considered that people with lower income and without conditions to buy medicine, search for alternative ways of treatment for the cure of their infirmities ${ }^{(0,14)}$. Data observed in other studies ${ }^{(9,14)}$ show that the population which makes uses of medicinal plants belong to poorer social classes.

Analyzing the results obtained in this study and the data of other researches regarding schooling of the researched population, it is evident that most of the people who search for the services of basic attention to health, as well as users of medicinal plants are subjects with low schooling and income who probably do not have financial conditions to look for private health services ${ }^{(5-6,8)}$. Besides that, the low purchase power of those people do not allow them to buy expensive medicine $\mathrm{e}^{(5-6,8)}$.

It should also be highlighted that in most of the researches involving the use of medicinal plants by the community, a great part of the subjects use the plants as alternative therapy for the treatment of health ${ }^{(6,14)}$.

According to the profile of the sample population, from the ten most reported plants, only seven are described in the National Phytotherapic
Form, as being plants for therapeutic purposes (Mint, Lemongrass, Pennyroyal, Bush lemongrass and Chamomile). According to that document, each one of them must be prepared in one way ${ }^{(15)}$. However, it was noticed that some plants are misused by the population.

The above mentioned plants, and which are part of the form, are indicated for cramps in general (mint), flatulence (mint and bush lemongrass), hepatic disorders (mint), intestine and uterine cramps (lemongrass), tranquilizers (lemongrass, bush lemongrass and chamomile), light situations of anxiety and insomnia (bush lemongrass and chamomile), dyspepsia and hypotension (Boldo), expectorant (pennyroyal and bush lemongrass), appetite stimulator, digestive disorders, gastrointestinal spasms, gallstones and cholecystitis (pennyroyal), abdominal cramps, stomach disorders and as digestive (lemongrass), healing medicine and for the treatment of burn (Aloe vera), intestine cramps, bruises and inflammatory processes of the mouth and the gum (chamomile) ${ }^{(16)}$. It is interesting to notice that most of the therapeutic uses of the plants do not confirm the report of the interviewees, except the lemongrass, the bush lemongrass and the chamomile which are used as tranquilizers; chamomile for cramps and aloe vera for burns. Besides that, the mint which is mentioned in this study for the treatment of hepatic disorders is not indicated for severe hepatic damage; and the bush lemongrass can cause gastric irritation ${ }^{(16)}$.

The ways of preparation indicated by the Form and the ones mentioned by the interviewees, in most of the cases, were also different. In a large number of plants the method of infusion of stems, leaves and/or flowers (mint, lemongrass, boldo, bush lemongrass and chamomile) are used.

In Brazil, the rules for the use of medicinal plants within the health services in linked to the National Phytotherapic Form, which is part of the Brazilian Pharmacopoeia, and brings the guidelines for the use of several medicinal plants. All the recommendations stablished by that form are based in scientific studies 
made in several countries ${ }^{(15)}$.

It is noticed that the use of plants with therapeutic purposes is common and that a great part of the community make use of species that are listed in the Brazilian Pharmacopoeia ${ }^{(5,9,10,17)}$. These data show that the studies made with the plants popularly used for alternative treatment are very important to validate their medicinal potential.

It can also be perceived that a large number of users cultivate the plant at home; which confirms most of the studies made with users of medicinal plants $^{(6,9,14)}$. This probably occurs because the cultivation of the plants makes the obtaining of the same by the users easier; besides that, their use is fresh and immediate ${ }^{(6)}$.

Another important datum is that the indication of use of the plants was mainly made by the family members, which means that the knowledge and use of the plant species comes from the family tradition which is passed on from generation to generation ${ }^{(5,9)}$.

It is important to highlight that the use of medicinal plants, in most of the times, was not indicated by a health professional, such as a nurse, chemist or doctor. Therefore, it is noticed that the population is making use of such therapists without the due assistance, which can brings risks for health once many of these species present a register of toxicity and contraindications ${ }^{(18)}$. However, many of these health professionals generally do not consider the medicinal plants as a therapeutic source precisely by the fact that they do not know the benefits and the risks of the same ${ }^{(19)}$.

It is noticed, however, that most of the users of medicinal plants believe that 'plants do not harm health', which may lead them to severe intoxication. So, it is necessary that the community is guided as to the form of use and preparation of the same, thus contributing for an alternative therapeutics in the health of the population, improving the quality of life and minimizing the costs for the Unified Health System. According to this, it is important that the health professionals, especially the nurses, are trained, so that they can contribute with the correct of usage of alternative therapies in Primary Attention to Health and that this practice must be incorporated in the Family Health Units ${ }^{(18)}$.

The promotion of health in the Family Health Strategy is a methodology which can provide quality of life and health for the population, and this is due to the resolution of the health problems and its determinants ${ }^{(12)}$. So, the use of the phytotherapy as complimentary therapeutics, can work as a tool of low economic cost, effective and in the assistance of the need of the population.

\section{Final Considerations}

The analysis of the knowledge and use of medicinal plants among the users of two Family Health Units in the county of Sinop, MT, Brazil, showed that 92.3\% mentioned 77 plants of habitual use for the treatment of several infirmity and only $7.6 \%$ did not used this complimentary therapy. The main clinical uses of these plans were: the flu, cramps, tranquilizers, stomachaches, hangover, wounds, bruises, deworming, burns, and control of the Diabetes Mellitus, infections, urinary infections and anti-hypertensive agent.

The most used ways of preparation were: infusion, decoction, juice and compress, and the parts of the plants that were more used were areal parts (leaves and flowers), roots and also the whole plant.

It is also notorious that there is a lack of a greater integration of the use of medicinal plants within the programs developed in the Family Health Units, once only $0.9 \%$ of the interviewed population acquired information in such plants with the health professionals. So, it can be stated that the researched population does not receive any subsidy referring to the correct use of the medicinal plants by parts of the service of local health, once there is no implantation of National Policy of Integrative and Complementary Practices in the Units where the research was made.

The nurse, as a professional inserted in the Family Health Strategy, exercises a fundamental role 
in the minimization or even in the prevention of cases of intoxication or other disorders resulting from the undue use of the medicinal plants, through activities of education in health.

The largest part of the population which makes use of medicinal plants in both communities, belong to the economical social classes $\mathrm{D}$ and $\mathrm{E}$ and this is common, once they do not have sufficient income to purchase medicine thus using plants as therapy. However, so that a medicinal plant can be effective as complimentary therapeutic manner, the assistance of a competent professional who is able to elaborate programs of education in health covering this theme and the need of the users is necessary.

For such, a greater training of these professionals is necessary with the incorporation of content which contemplate phytoterapy in the graduation courses, which must contribute for the correct use of theses therapeutic resources, providing better conditions of health with therapeutics of low cost and rescuing values of the popular culture.

The study presents as a limitation the fact that it covers only two communities of the county of Sinop. Therefore, it is proposed that other researches should be developed, in order to know the reality of other communities. Also, it was not possible to verify the consonance of the indications of use, manner of preparation and dosage with these individuals concerning the ones mentioned in the bibliography with scientific evidence. Researches with this purpose could be a reference for additional studies in order to enhance the possibilities of use of the indicated species, or even prove the inefficiency or impropriety of their use.

\section{Collaborations}

Lima DF and Cavalcanti PP participated in the conception and elaboration of the project, collection and analyses of the data, writing and critical analyzes of the article. Pereira DL, Franciscon FF and Lima VS contributed with the making of the scientific article. Reis C was responsible for the whole critical revision of the project and the article.

\section{References}

1. Ferro D. Fitoterapia: conceitos clínicos. São Paulo: Atheneu; 2008.

2. Ministério da Saúde (BR). A Fitoterapia no SUS e o Programa de Pesquisa de Plantas Medicinais da Central de Medicamentos. Brasília: Ministério da Saúde; 2006.

3. Conselho Nacional de Saúde. Portaria ${ }^{\circ}$ 971, de 03 de maio de 2006. Aprovação da Política Nacional de Práticas Integrativas e Complementares no Sistema Único de Saúde. Diário Oficial da União, Brasília, DF, 04 maio 2006. Seção1.

4. Bruning MCR, Mosegui GBG, Vianna CMM. A utilização da fitoterapia e de plantas medicinais em unidades básicas de saúde nos municípios de Cascavel e Foz do Iguaçu - Paraná: a visão dos profissionais de saúde. Ciênc Saúde Coletiva. 2012; 17(10):2675-85.

5. Oliveira ER, Menini Neto L. Levantamento etnobotânico de plantas medicinais utilizadas pelos moradores do povoado de Manejo, Lima Duarte MG. Rev Bras Plantas Med. 2012; 14(2):311-20.

6. Brasileiro GB, Pizziolo VR, Matos DS, Germano AM, Jamal CM. Plantas medicinais utilizadas pela população atendida no "Programa de Saúde da Família”, Governador Valadares-MG. Rev Bras Ciênc Farm. 2008; 44(4):630-6.

7. Instituto Brasileiro de Geografia e Estatística (IBGE). Estimativa populacional de 2009 [Internet]. [citado 2011 mar 21]. Disponível em: http://www.ibge.gov.br/home/estatistica/ populacao/estimativa2009/estimativa.shtm.

8. Pereira ZV, Mussury RM, Almeida AB, Sangalli A. Medicinal plants used by Ponta Porã community, Mato Grosso do Sul State Sul State. Acta Sci Biol Sci. 2009; 31(3):293-9.

9. Sousa MJM, Moral FF, Nascimento GNL, Soares NP, Ferreira-Aversi TA. Medicinal plants used by Itamaraty community nearby Anápolis, Goiás State, Brazil. Acta Sci Health Sci. 2010; 32(2):17784. 
10. Giraldi M, Hanazaki N. Uso e conhecimento tradicional de plantas medicinais no Sertão do Ribeirão, Florianópolis, SC, Brasil. Acta Bot Bras. 2010; 24(2):395-406.

11. Vieira FC, Amaral AF. Estudo etnobotânico das plantas medicinais da localidade rural de Alagoas em Patos de Minas. Perquirēre Rev Eletr Pesq [periódico na Internet]. 2008 [citado 2013 mar 21]; 5(5):[cerca de 9p.]. Disponível em:http://perquirere.unipam.edu.br/ documents/.23456/34929/artigo_fabiane.pdf

12. Lopes MSV, Machado MFAS, Barroso LMM, Macêdo EMT, Costa RP, Furtado LCS. Health promotion in the perception of the Strategy of Family Health nursing professionals. Rev Rene. 2013; 14(1):6070.

13. Albuquerque UP, Lucena RFP, Alencar NL. Métodos e técnicas para a coleta de dados etnobotânicos. $2^{\underline{a}}$ ed. Recife: COMUNIGRAF; 2008.

14. Ethur LZ, Jobim JC, Ritter JG, Oliveira G, Trindade BS. Comércio formal e perfil de consumidores de plantas medicinais e fitoterápicos no município de Itaqui-RS. Rev Bras Plantas Med. 2011; 13(2):1218.

15. Anvisa. Consulta pública $\mathrm{n}^{\circ} 73$, de 16 de julho de 2010. Formulário Nacional Fitoterápico
[Internet]. [citado 2013 mar 21]. Disponível em:http://portal.anvisa.gov.br/wps/wcm/ connect/5b996d8047458f699895dc3fbc6735/ $\mathrm{CP}+\mathrm{N} \% \mathrm{C} 2 \% \mathrm{BA}+73+\mathrm{COFAR} . p d f ? \mathrm{MOD}=\mathrm{AJPERES}$.

16. Ministério da Saúde (BR). Instrução Normativa $\mathrm{n}$ ำ 5, de 31 de março de 2010. Estabelece a lista de referências bibliográficas para avaliação de segurança e eficácia de medicamentos fitoterápicos. Diário Oficial da União, Brasília, DF. 05 abr. 2010. Seção 1.

17. Albertasse PD, Thotmaz LD, Andrade MA. Plantas medicinais e seus usos na comunidade da Barra do Jucu, Vila Velha, ES. Rev Bras Plantas Med. 2012; 12(3):250-60.

18. Tomazzoni MI, Negrelle RRB, Centa ML. Fitoterapia popular: a busca instrumental enquanto prática terapêutica. Texto Contexto Enferm. 2006: 15(1):115-21.

19. Borges AM, Almeida C, Lopes CV, Heck RM, Barbieri RL. Plantas medicinais no campo educacional: saberes relacionados ao boldo-gambá. Enferm Comunitaria [periódico na Internet]. 2011 [citado 2014 maio 9]; 7(2)[cerca de 6 p]. Disponivel en: http://ainfo.cnptia.embrapa.br/digital/bitstream/item/49772/1/artigo-publicado-revista-enfermeria-comunitaria.pdf. 